\title{
Vooronderstellings in die verstaansproses met spesifieke verwysing na Heinrich Ott se Christologiese model
}

\author{
M D Robbertze \& J H Koekemoer \\ Universiteit van Pretoria
}

\begin{abstract}
Presuppositions in the hermeneutical process, with spesific reference to the christological model of Heinrich Ott
\end{abstract}

This article strives to examine the characteristics of the interpretation process, as well as the role that presuppositions play in it. A conclusion is reached that presuppositionless interpretation does not exist. Interpretation can only be scientifically true if we are aware of our presuppositions, and if we articulate them clearly. A final decisive interpretation is therefore out of the question. This does not entail relativism, it rather involves a multiplicity of viewpoints with relation to a specific issue. In order to illustrate how presuppositions play a role in the interpretation process, there follows an examination of philosophical conceptions - specifically the existential philosophy - in the christological model of Heinrich Ott as expounded in his Die Antwort des Glaubens.

\section{PROBI FEMSTEI I ING}

Die ter sprake bring van die Bybelse boodskap vir die moderne mens is vir die teoloog van wesenlike belang. Die Bybelse boodskap moet by die mens tuiskom. Daarom mag dit nie bloot 'n herhaling van die teks wees nie. Die vraag is natuurlik hoe die teks van die Bybel opnuut in die hede by die mens van vandag tuis kan kom.

- Voorgelê en aanvaar as deel van die vereistes vir die MDiv-graad, Fakulteit Teologie (Afd A), Universiteit van Pretoria, onder leiding van prof dr J H Koekemoer. Finansiële bystand van die Raad vir Geesteswetenskaplike Navorsing word hiermee erken. Standpunte wat hier uitgespreek word is die van die outeur en nie noodwendig dié van die RGN nie. 
Die antwoord op die vraag dui in die rigting van die interpretasie van die Bybelse teks. Dit beteken dat die oorspronklike woorde nie sonder meer herhaal kan word nie. Indien dit gebeur, kan dit wees dat dit vir die moderne mens in sy omstandighede niks sea nie. 'n Teks uit die verlede, in dié geval ook die Bybelse teks, het gespreek in sy eie historiese raamwerk en kan alleen verstaan en verstaanbaar gemaak word deur die verstaansvoorwaardes van die nuwe raamwerk in ag te neem en tot spreke te bring. H Ott het in die daarstel van 'n Christologiese model hiermee erns gemaak. Om sy poging te kan verstaan sal daar allereers sekerheid gekry moet word oor die aard van verstaan en die faktore wat daarin 'n rol speel. In die lig van genoemde agtergrond sal Ott se model eers reg waardeer kan word.

\section{BESINNING OOR WAT VERSTAAN BEHELS}

Om enige teks te lees, behels meer as om bloot kennis te neem van die woorde wat in die teks geskryf staan. 'n Teks word gelees met die doel om dit te verstaan en verstaanbaar te maak. So speel die hermeneutiese proses by die lees en verstaan van enige teks dan ook 'n spesifieke rol.

Tradisioneel is hermeneutiek gesien as die teorie van die eksegese. Dit is gesien as 'n blote hulpdissipline vir die eksegese. Daarom het dit gegaan om die daarstel van 'n stel reëls wat as hulpmiddel by die interpretasie van tekste moes dien. Palmer (1969:34) omskryf die tradisonele siening soos volg: 'The oldest and probably still the most widespread understanding of the word "hermeneutics" refers to the principles of biblical interpretation. There is historical justification for this definition, since the word came into modern use precisely as the need arose for books setting forth the rules for proper exegesis of Scripture.'

Tans word hierdie stelling nie meer ongekwalifiseerd aanvaar nie. Die hermeneutiek wil nie soseer 'n aantal reëls vir die eksegese of die verstaansproses daarstel nie, maar dit wil die basiese beginsels wat vir die verstaansproses nodig is, aandui. Palmer (1969:68) stel dit soos volg:

...the hermeneutical problem, is a specific instance of the event of understanding: it always involves language, the confronting of another human horizon, an act of historical penetration of the text. Hermeneutics needs to go even more deeply into this complex act of understanding; it must struggle to formulate a theory of linguistic and historical understanding as it functions in text interpretations. Such a theory must be harmonized with and related to a general phenomenology of understanding; at the same time, it will itself contribute to such a general field. 
Juis omdat die verstaansproses nie ' $n$ vanselfsprekende saak is nie en omdat dit deur 'n hele reeks faktore beïnvloed word, het hierdie hermeneutiese proses so noodsaaklik geword. Hier gaan dit om 'n grondtendens in die teologie waarmee daar überhaupt geworstel word.

Die woord 'hermeneutiek' word tans in verskillende dissiplines en kontekste met ' $n$ verskeidenheid betekenisnuanses gebruik. Hier word met 'hermeneutiek' bedoel, die nadenke oor en die leer omtrent die interpretasie van oorgelewerde tekste. Interpretasie is verstaansbemiddeling, dit wil sê dit gaan om die geheel van faktore en aktiwiteite wat in die spel kom by die ontsluiting en toe-eiening van die sin wat deur 'n teks gekommunikeer word. Die verstaansproses kan verskillende vorme aanneem.

Die aandag kan gefokus word op die aard, die moontlikheid en die doel van verstaan. Daar kan ook gekonsentreer word op die metodiese riglyne wat vir doeltreffende verstaan gevolg moet word. Hierdie verskillende vorme van die verstaansproses staan nooit los van mekaar nie, maar vorm altyd 'n geheel. In die verlede is die standpunt gehuldig dat wanneer ons 'n teks uit die verlede wil verstaan, ons die teks in sy geheel verstaan slegs in die mate wat ons die afsonderlike dele daarvan verstaan, en die deel weer wanneer ons die geheel verstaan. Dit staan bekend as die hermeneutiese sirkel.

Die geheel waarvan hier sprake is, is die geheel van die historiese horison waarbinne die teks verskyn het. Wanneer ons 'n teks uit die verlede wil begryp, moet ons dit terugplaas in sy historiese horison. Ons moet sy historiese horison konstrueer soos die mense van daardie tyd die teks beleef het. So word die hermeneutiese sirkel gehistoriseer. Die hermeneutiese sirkel word binne die tradisionele hermeneutiek ook verpsigologiseer. Dit veronderstel dat 'n mens 'n gedagte alleen vanuit sy ontstaansgeskiedenis in die menslke psige kan begryp.

Die vraag is of dit enigsins moontlik is vir 'n mens van vandag om hom so terug te verplaas. Elke mens is produk van en deel van sy tyd en van die wêreld en geskiedenis van sy tyd. Die probleem is verder dat as hierdie beginsel eensydig toegepas word, die mens van vandag losgemaak word van sy tyd en sy wêreld, terwyl dit juis hier en nou is dat hy die teks verstaanbaar moet hoor. Die teks moet vertaal word vir die mens van vandag.

Die manier waarop die verstaansproses tans verstaan word, is ten nouste gekoppel aan die hermeneutiese insigte van E Fuchs en G Ebeling op die terrein van die teologie, en van $\mathrm{H} \mathrm{G}$ Gadamer op die terrein van die filosofie: 
The approach to the New Testament which has come to be known as the new hermeneutic is associated most closely with the works of Ernst Fuchs and Gerhard Ebeling. Both of these writers insist on its practical relevance to the world of today. How does language, especially the language of the Bible, strike home [treffen] to the modern hearer? How may its words so reach through into his own understanding that when he repeats them they will be his words? How may the word of God become a living word which is heard anew?

(Thiselton 1986:78)

Die hermeneutiek van Fuchs en Ebeling sluit in 'n sekere sin aan by die hermeneutiek van Bultmann en berus in 'n groot mate ook op die filosofie van Heidegger en Gadamer. Vir Heidegger dui die term hermeneutiek op die verstaansproses self.

In hierdie verband stel Gadamer dat waarheid nie metodologies bekom of bereik kan word nie, maar alleen dialekties. In die metodologiese ondersoek is dit die ondersoekende subjek wat leiding neem, kontrole uitoefen en manipuleer; in dialektiek is dit die saak waarmee kennis gemaak word wat die vraag stel waarop die ondersoekende subjek antwoord.

By al hierdie denkers word daar ook besondere klem gelê op die betekenis en krag van taal. Taal is nie maar net 'n instrument van kommunikasie nie, dit is ' $n$ gebeurtenis, dit bring iets tot stand. Teologies gesproke beteken dit dat die verkondiging 'n taalgebeurtenis is deurdat dit die liggaam van Christus teenwoordig stel. Fuchs en Ebeling sien taal dus as veel meer as die verskaffing van informasie. 'n Mens moet nie vra na wat woorde bevat nie, maar na wat hulle teenwoordig stel. Vir beide Fuchs en Ebeling is dit van die grootste belang dat die teks van die Bybel opnuut aan die woord moet kom vir die mens van vandag. Daarom is hermeneutiek vir Ebeling nie 'n klomp reëls nie, maar die verstaansproses self. Dit is wat Ebeling (1967:337) bedoel as hy sê: 'Wenn, wie wir uns klarmachten, das Wort selbst hermeneutisches Prinzip ist, also das ist, von dem Verstehen ausgeht, in dem es seinen Ursprung hat, so muss also Hermeneutik als Lehre vom Wort aus dem Wort geschehen selbst entspringen. Hermeneutik muss darum, um Interpretationshilfe zu sein, selber Interpretation sein.'

Die noodsaaklike vooronderstelling vir verstaan wat deur dié denkers uitgelig word, is die voorafgaande lewensverhouding en lewenssamehang wat daar by die uitlegger aanwesig is, met betrekking tot die saak waarom dit gaan. Fuchs (1964: 124) stel dit so: Die hoorder moet betrokke wees om gesprek moontlik te maak. Hy noem hierdie betrokkenheid Einverständnis (Fuchs 1968:171-181, 239-243). Dit is die bereidheid tot betrokkenheid, en die aanwesigheid van 'n gemeenskaplike ter- 
rein van gesprek. Hy illustreer hierdie betrokkenheid aan die hand van die situasie in die gesin: 'At home one does not speak so that people may understand, but because people understand' (Fuchs 1964:124). Deur hierdie Einverständnis ontmoet die horisonne van die wêreld van die spreker en die hoorder mekaar en smelt hulle saam om so 'n gemeenskaplike wêreld of terrein van verstaan tot stand te bring.

Hierdeur ontstaan in werklikheid ' $n$ nuwe wêreld en deur hierdie nuwe wèreld word die mens se ou wêreld verander, en word daar 'n einde gemaak aan sy ou norme en voorkeure. Dit is dan ook verder die oortuiging van die denkers dat vooronderstellingslose verstaan nie moontlik is nie. Afgesien van die feit dat die teoloog deel vorm van 'n historiese werklikheid waardeur hy bepaal word en waarvan hy hom nie kan losmaak of dink nie, word uitgegaan van die feit dat kommunikasie 'n dialogiese relasie veronderstel. Dit wat verstaan moet word, moet reeds bekend wees.

It is well known that Rudolf Bultmann, among others has repudiated the idea that an interpreter can 'understand' the New Testament independently of his own prior questions. One cannot for example, understand a text about economic history unless one already has some concept of what a society and an economy is. In this sense Bultmann rightly insits, 'There cannot be any such thing as presuppositionless exegesis....' Historical understanding always presupposes a relation of the interpreter to the subject matter that is...expressed in the text. The demand that the interpreter must silence his subjectivity...in order to attain as objective knowledge is therefore the most absurd one that can be imagined. Preunderstanding, or a prior life-relation to the subject matter of the text, implies not a prejudice, but a way of raising questions.

(Thiselton 1985:313)

Omdat die teoloog reeds in 'n historiese tradisie staan, is daar by hom onvermydelik vooronderstellings aanwesig. Hierdie vooronderstellings van die indiwidu, eerder as sy oordele, is volgens Gadamer die historiese werklikheid van sy bestaan. Gadamer se doel is nie om onverantwoordelike of selfgewilde verstaan in die geesteswetenskappe te regverdig nie, maar om te wys dat alle menslike verstaan beperk is, in dié sin dat dit altyd 'n dimensie van implisiete oordeel bevat. Hierdie dimensie van implisiete oordeel vorm 'n saak of objek op 'n wyse wat ons nie kan antisipeer of beheer nie. Dit impliseer 'n eindige beperkte visie van menslike verstaan (Gadamer 1975:239-240). 
Die term 'hermeneutiese situasie' dui op die konkrete geheel van vooronderstellings en grondinsigte wat ons met ons meebring. Ons kan ook sê dat dit ons verstaanshorison is. Hierdie horison mag ons egter nie sien as 'n fester Bestand von Meinungen und Wertungen sonder diepte-dimensie nie (Gadamer 1960:289). Die horison van die hede konstitueer hom nie los van die verlede nie. Die feit dat ons reeds oor 'n horison beskik, bring mee dat ons in die wetenskap ons horison kan verhelder en kontroleer.

Bewus van die vooronderstellings wat gegrond is in die historiese en kulturele sfeer waarin die interpreteerder hom bevind, word hy bewus van die afstand in tyd en omstandighede tussen sy tyd en die tyd waarin die teks ontstaan het. Eers as hy van hierdie afstand bewus is, kan hy die horison van sy wêreld uitbrei totdat dit saamsmelt met dié van die teks. Dit is in hierdie sin dat Gadamer oordeel dat geen saak of teks in 'n historiese vakuum of suiwer logiese ruimte bestaan nie. Elke subjek van verstaan bestaan binne 'n Wirkungsgeschichte (Gadamer 1975:267f, 305f, $310 \mathrm{f}, 324 \mathrm{f}, 351 \mathrm{f}$ ) waarbinne horisonsversmelting plaasvind. Laasgenoemde is 'n ineenvloeiing van die historiese horison van die teks met die horison van die interpreteerder. Dit maak verstaan 'n voortdurende proses van interpretasie en dialoog tussen die verlede en die hede.

Die versmelting van horisonne waarvan Gadamer praat, beteken nie dat ons met afsonderlike horisonne te doen het wat daarna met mekaar versmelt in die interpretasieproses nie. In werklikheid is daar maar een horison wat in 'n gedurige wisselwerking tussen hede en verlede steeds verder uitkring en verder vorm aanneem. Tussen beide horisonne moet 'n gesprek tot stand kom. Die interpreteerder plaas sy eie vooronderstellings waarvan hy bewus geword het, op die spel. So kom daar in die spel van die gesprek 'n realiteit tot uiting wat nie uitsluitlik die interpreteerder of die outeur s'n is nie, maar 'n gemeenskaplike saak (Gadamer 1960:274366). Eers dán is Einverständnis (Fuchs) moontlik en so kan daar dialoog van vraag en antwoord ontstaan tussen byvoorbeeld die teoloog en die teks. Dit beteken dat die interpreteerder nie blind mag wees vir wat daar alreeds tradisioneel rondom die teks opgebou is en wat toegang tot die teks versper nie. Die interpreteerder moet hom kan distansieer van alle tradisionele interpretasies wat nie reg aan die teks laat geskied nie.

Die vraag ontstaan of, in die lig van bogenoemde argumente vooronderstellingslose verstaan moontlik is, en indien nie, of vooronderstellings hoegenaamd gekorrigeer kan word. 


\section{IS VOORONDERSTELIINGSLOSE VERSTAAN MOONIIIK?}

Vandag word bykans allerweë erken dat iemand wat die geskiedenis, of gebeure in die geskiedenis, of tekste uit die geskiedenis bestudeer, dit nie kan doen as 'n onbetrokke waarnemer nie. Hy sal hom nooit kan losmaak van die plek waar hy staan, van standpunte wat hy huldig, en van die invloede waaraan hy onderhewig is nie. Rohrbaugh (1987:23) merk tereg op: 'Human perception is selective limited culture bound and prone to be unaware that it is any or all of the above. The cognitive maps with which we select, sort and categorize complex data interpose themselves between events and our interpretation of them whether we like it or not.'

Gadamer wys daarop dat ons menslike denke standpuntgebonde is. Vele nuwe sinsmoontlikhede het met die verloop van tyd na vore getree. Begrippe van vroeër het ' $n$ ander betekenisinhoud gekry. Om ons eietydse begrippe tersyde te stel, is nie so eenvoudig nie; dit maak immers aan die een kant ons begrip van 'n saak moontlik, en aan die ander kant beïnvloed dit ons verstaan van 'n saak. Wat wel waar is, is dat ons interpretasie alleen wetenkaplik is wanneer ons poog om so goed moontlik bewus te wees van ons vooronderstellings.

Die vooronderstellings wat daar by elke ondersoek aanwesig is, is van voorwetenskaplike en wetenskaplike aard. Wetenskaplike verstaan hef nie vooronderstellings op nie maar maak die interpreteerder bewus daarvan. Die aanwesigheid van vooronderstellings lei tot die dinamiese voorlopigheid van wetenskaplike verstaan, asook 'n groter beskeidenheid en openheid teenoor ons bevindinge. Hoewel geen interpreteerder sy vooringenomenheid kan ontken nie, mag hy nie toelaat dat dit oorheersend word in sy interpretasie nie. Hy sal hom nie van sy vooronderstellings kan losmaak nie, maar hy moet altyd 'n bepaalde objektiwiteit nastreef. Omdat die teoloog die teks nie as 'n onbetrokke waarnemer kan benader nie, sal daar altyd ' $n$ bepaalde vooringenomenheid wees waarin sekere vooronderstellings ' $n$ rol speel.

Die teoloog sal die aanspraak van die teks eers verstaan wanneer hy deur die saak aangespreek word wat daarin voorkom. Denkers soos Fuchs en Ebeling wys op laasgenoemde as hulle die ommekeer van die subjek-objek-skema bepleit: Die teks word gesien as die werklike subjek en die interpreteerder as die objek. Volgens Ebeling moet die teks ons eers 'vertaal' voordat ons die teks kan 'vertaal'. Die teks werp lig op die wêreld van die interpreteerder en help hom om beter te verstaan: 'Das primäre Verstehensphänomen ist nicht das Verstehen von Sprache, sondern das Verstehen durch Sprache. Das Wort ist eigentlich nicht Objekt des Verstehensproblems aufgibt, zu dessen Lösung es der Auslegung und eben darum auch der Hermeneutik als der Verstehenslehre bedarf. Vielmehr ist das Wort dasjenige, was Verstehener ofnett und vermittelt' (Ebeling 1967:333). 
Die verstaansproses vind in 'n sirkelgang plaas tussen interpreteerder en teks. Die teoloog sal dus met sy voorlopige vrae en vooronderstelings na die teks toe gaan. Die teks kom dan aan die woord en werp lig op die vrae en vooronderstellings. So word die teoloog in staat gestel om sy vrae en vooronderstelings te korrigeer. Hy word in staat gestel om sy vrae beter te formuleer en sy vooronderstellings bewustelik te maak. Dit maak die teks verstaanbaarder en duideliker. Die saak waarom dit gaan, word al hoe meer tot spreke gebring in die situasie van die interpreteerder. Dit is waarom dit in die teologie gaan: Die Bybelteks uit die verlede moet opnuut aan die woord kom in die hede. Daar is geen interpretasie sonder ' $n$ verhouding met die hede nie. Geen interpretasie is dus permanent nie. 'n Oorgelewerde teks, byvoorbeeld die Bybel, moet verstaan word in die hermeneutiese situasie waarin die teoloog hom bevind, dit is in relasie tot die hede. Dit beteken nie dat ons onnadenkend staan teenoor die verlede nie; dit beteken alleen dat 'n mens sal erken dat betekenis altyd betekenis vir jou is. Ook beteken dit nie dat betekenis nou geheel en al anders sal wees as in die verlede nie. Dit wys net daarop dat betekenis verband hou met die hede. Verstaan is dus altyd gekondisioneer deur voorverstaan, wat onder andere opkom vanuit die hede, die huidige situasie waarin die interpreteerder hom bevind.

Hierdie voorverstaan kan en moet bewustelik deur die teoloog gemaak word in soverre as wat hy die toepasbaarheid van sy interpretasie en die geldigheid daarvan wil aandui. Maar omdat so 'n selfrefleksie nooit kan lei tot die opheldering van alle voorverstaan nie, bly alle verstaan kontekstueel en gedeeltelik. Belangrik is egter dat vooronderstellings bewustelik gemaak kan word en getoets kan word in terme van die saak self. Sou die voorverstaan ongenoegsaam wees, kan die eensydigheid daarvan dan blootgestel word en is die pad oop vir verdere interpretasie. Vooronderstellings kan dus interpretatief wees in soverre as wat hulle die vorige vooronderstellings aan die lig bring en korreksies daarop aanbring. Vooronderstellings maak kritiek nie onmoontlik nie, dit maak dit juis noodsaaklik.

Daar is tot hiertoe gepoog om ondersoek in te stel na die aard van die verstaansproses en die rol wat vooronderstellings daarin speel. Daar is tot die gevolgtrekking gekom dat vooronderstellingslose verstaan nie moontlik is nie, en dat ons interpretasies alleen wetenskaplik eg is as ons ons vooronderstellings duidelik en bewustelik artikuleer. Dit beteken nie 'n verval in relativisme of willekeur nie, maar dui eerder die ontsluiering van 'n veelheid van perspektiewe op dieselfde saak aan. Hierin het Ott 'n baie besliste pad aangedui deurdat hy in sy beoefening van die teologie en in die daarstel van 'n Christologiese model die rol van vooronderstellings in die verstaansproses nie alleen erken nie, maar dit ook daadwerklik hanteer. 


\section{DIE WERKMETODE VAN HEINRICH OTT}

Heinrich Ott is die opvolger van Karl Barth in die Departement Dogmatiek aan die Universiteit van Basel, Switserland. Voordat hy die pos beklee, is hy 'n gasdosent aan die Universiteit van Basel, en terselfdertyd ook ' $n$ voltydse predikant in een van die plaaslike gemeentes.

Ott maak in sy publikasies geen geheim daarvan nie dat hy Barth se werk voortsit; hy sien net soos Barth die noodsaak vir'n teosentrisme. Tog steun hy ook sterk op die insigte van Rudolf Bultmann en die filosoof Martin Heidegger. Bultmann toon 'n sterk belangstelling in die probleem van menslike bestaan en die tuisbring van die kerugma aan die mens. Hierby sluit Ott duidelik aan in sy teologiese insigte.

Die volgende publikasies verskyn onder andere uit Ott se pen: Gott (1971); Wirklichkeit und Glaube: Zur theologischen Erbe Dietrich Bonhoeffers (1971); Die Antwort des Glaubens (1981). Hy is ook mede-outeur van die volgende publikasies: Kirche als Dialog (1969); Theologie, Offenbarung Gotteserkenntniss (1974); Schöpfung und Erlösung (1977). Ott publiseer ook gereeld artikels in verskeie teologiese tydskrifte, veral in Theologische Zeitschrift.

Teologie moet volgens Ott die Christelike verkondiging en die getuienis van die waarheid tot diens wees. Sy boek, Die Antwort des Glaubens wil dan ook 'n antwoord wees op die vraag, "Welche Wahrheit hat die Botschaft, die wir als Christen glauben und verkundigen?' (Ott 1981:22). In sy beantwoording bly hy by uitgesoekte onderwerpe wat hy poog om in 'n eksistensiale idioom vir die moderne gelowige en ongelowige uiteen te sit en die invloed daarvan vir die huidige situasie verstaanbaar te maak (Naude 1981:30). Dit is waarom dit in die verstaansproses immers gaan, dat ' $n$ teks uit die verlede opnuut in die hede tot spreke gebring moet word. Daarom sal, volgens Ott, 'n Christologie ook verstaanbaar moet wees in die hede. Die Bybelse boodskap oor Christus moet opnuut tot spreke gebring word. Dit moet só tot spreke gebring word dat dit die moderne mens in sy bestaan raak en aanspreek. Met hierdie poging sluit Ott aan by 'n grondbegrip in die eksistensiefilosofie, naamlik die situasie: Die situasie dui op die menslike wêreld waarin die mens altyd eksisterend besig is en in ontmoeting tree met sy wêreld en sy medemens.

\subsection{Vertrekpunt en ontvouing van die model}

Die model neem ' $n$ aanvang met ' $n$ verwysing na die gevalle mens. Ott beskryf die mens wat hom in 'n onheilsituasie bevind. In hierdie onheilsituasie is die funksie van 'n Christologie soteriologies van aard. Dit is so, omdat Christus die gevalle mens se onheilsituasie ophef met sy koms.

Ott struktureer sy model vanuit die kant van die mens wat deur God in sy persoonlike bestaan aangespreek word. In die eksistensiefilosofie gaan dit volgens 
Stump (1982:487) ook om die mens in sy persoonlike bestaan: 'Existentialism is a mode of philosophy which focuses upon the existing individual person; instead of searching for truth in distant universal concepts, existentialism is concerned with the authentic concerns of concrete existing individuals as they face choices and decisions in daily life.'

Hierdie mens word volgens Ott deur God aangespreek, en in hierdie aanspraak van God vra hy na die wil van God. Dit is aan hierdie vraende mens wat die Christologiese model van Ott die antwoorde wil verskaf. Hierdie model het ten doel dat die vraende mens Jesus Christus moet ontmoet. Dit wil die vraende mens by die deurslaggewende, die kruis- en die opstandingsgebeure uitbring. Verder wil dit die mens lei en rig na die misterie van die preëksistensie en die verhoging van Christus (Naude 1981:30).

Ott probeer in sy Christologiese model die vrae van die mens, wat deur God in 'n gespreksituasie betrek is, beantwoord. Die klem wat hy laat val op die vraende mens, is in eksistensiefilosofiese terme 'n bestaansoorsprong eie aan die mens.

As vraende kry die mens ook 'n taak-karakter: Telkens moet hy opnuut in vryheid, maar in verantwoordelikheid, 'n antwoord kies. In die sin is 'n antwoord 'n beleefde ontmoeting, en nie 'n starre abstraksie nie. Gesien in die lig van die eksistensiefilosofiese opvattings, is die antwoord wat Ott aan die vraende mens wil gee, gerig op die totstandkoming van die 'eintlike' of egte bestaan van die mens.

\subsection{Ott se Christologiese model}

Ott skryf sy Christologiese model onder die opskrif, Die Sendung des Sohnes (Ott 1981:229). Hiermee wil hy aandui dat God sy Seun na die mens, wat in 'n onheilsituasie verkeer, gestuur het. Hierdie onheilsituasie van die mens speel 'n bepalende rol in sy verstaan van die Bybelse boodskap en die daarstel van 'n Christologiese model. Die onheilsituasie waarna hy verwys, kan in verband gebring word met dit wat Jaspers (1883-1969) as grenssituasies aandui: Dit gaan om skuld, stryd, lyding en die dood. Verder kan dit ook met die krisiskarakter wat so eie aan die eksistensiefilosofie is, in verband gebring word. Hierdie krisiskarakter kom tot stand as gevolg van die magteloosheid en moedeloosheid wat daar heers na die eerste en tweede wêreldoorloë.

Daar word dan gepoog om ten spyte hiervan die sin van die menslike eksistensie aan te dui. De Beer (1982:32) stel dit soos volg:

Die krisis van die onmag van die magtige mens soos dit manifisteer in wêreldoorlog een en twee sou lei na pogings tot verdieping deur die eksistensiefilosofie. In die bedreiging en ontwrigtinge van sosiale 
verbande, sedeloosheid, nihilisme, organiese en psigiese siektes, selfvernietiging, politieke verskuiwings en skynheiligheid moes aan die sin van indiwiduele mensebestaan aandag gegee word. Hierdie poging tref ons veral aan in die eksistensiefilosofie.

Die sending van die Seun dui daarop dat God 'n gesprek met hierdie mens wil voer. Die mens wat betrokke raak in die gesprek, vra na die wil van God. 'n Bespreking van die predestinasie bring vir Ott die vraag na die wil van God na vore. Ott bespreek die predestinasieleer as 'n antwoord op die vraag van die mens na die wil van God. Hy wys daarop dat 'n mens rekening moet hou met die feit dat die situasie waarin die predestinasieleer hierop moet antwoord, verskil van die situasie waarin die leer ontstaan het. Die tradisionele vraagstukke in die predestinasieleer wentel om die indiwiduele sieleheil. Tradisioneel was die vraag, soos dit ontwikkel is deur Augustinus en Calvyn, die vraag na persoonlike sieleheil. Vrae soos 'Wie word gered?', 'Is ek gered?', is beantwoord deur na God te verwys wat red wie Hy wil. Ook beantwoord die predestinasieleer die vraag waarom gelowiges gered en goddeloses verlore gaan. Hierop antwoord Calvyn met sy dubbele predestinasieleer. Hy kom na vore met ' $n$ leer van dubbele verkiesing en verwerping. God het in sy ewige raadsbesluit bepaal watter mense Hy eenmaal tot die heil gaan aanneem en watter $\mathrm{Hy}$ gaan verwerp.

Tydens en na die tweede wêreldoorlog het toestande ontstaan wat Europese teoloë laat vra het na die heil van die lydende mensheid in sy geheel. Omdat die verstaanshorison van die moderne mens verander het, kom die vraag nou in 'n nuwe gestalte, naamlik die sin van my lewe in samehang met die lewens van alle ander mense, ter sprake.

Ott is hierin duidelik bewus van die vooronderstellings wat gegrond is in die historiese en kulturele sfeer waarin die interpreteerder hom bevind. Hy is bewus van die afstand in tyd tussen sy tyd en die tyd waarin die vraagstuk aanvanklik ontstaan het. Hy is dus nie blind vir dit wat tradisioneel rondom die vraagstuk opgebou is nie. Hiermee toon hy aan dat hy besef dat verstaan gekondisioneer is deur voorverstaan, wat onder andere opkom vanuit die hede, die huidige situasie waarin die interpreteerder hom bevind, en vanwaar sy verstaansproses gerig word.

\subsubsection{Die heilsgeskiedenis}

'n Bespreking van die predestinasieleer bring die vraag na die wil van God na vore, die vraag of hierdie wil van God'n aanwysbare geskiedenis het, met ander woorde of daar iets soos ' $n$ heilsgeskiedenis bestaan. 
In 'n poging tot ' $n$ antwoord maan Ott teen 'n verobjektivering van die heilsdade. Die term heilsgeskiedenis kan op 'n chronologiese opeenvolging van heilsdade, volgens 'n definitiewe plan van God dui. Ott dink egter in 'n ander rigting. Hy stel dat mense God alleen kan bedink; hulle kan net van Hom praat indien hulle van sy verhouding met hulle praat.

God het nie planne wat Hy uitstal nie, maar $\mathrm{Hy}$ het sy wil en aanspraak op ons lewe geopenbaar, dit wil sê nie wat Hy beplan om alles agtermekaar te doen nie, maar dit wat Hy met ons wil. Dit wat God wil, geskied in die tyd en binne 'n gemeenskapshorison. Die Christelike geloof geskied ook altyd binne 'n geloofshorison of geloofsgemeenskap. God word egter nie deur elke gelowige op dieselfde wyse ervaar nie. ' $n$ Mens moet erken dat daar wel sprake kan wees van 'n geskiedenis van Goddelike ontmoetinge, 'n Geschichte des göttlichen Begegnens (Ott 1981: 245).

Wat die aard van die Goddelike ontmoeting op bepaalde oomblikke in die geskiedenis betref, moet daar nie kunsmatig 'n skeiding tussen woorde en feite gemaak word nie. So sou die opstanding as blote feit niksseggend wees, maar as 'n woord wat aanspraak maak op ons lewens is dit betekenisvol. Die heil in die opstanding word eers duidelik as dit my aanspreek. 'Als reines Faktum wäre es nichts, sondern nur als bedeutsames, das heisst als ein Geschehnis das bereits ein Wort, ein Anspruch einschliesst. Wir müssen uns hier auf einen Grundsatz der Ontologie geschichtlicher Wirklichkeit besinnen: Das geschichtlich Wirkliche ist zugleich das Bedeutsame: das Bedeutsame ist das Wirkliche' (Ott 1981:246).

Jesus Christus is die inhoud van die woord en wil van God. Die vraag hoe hierdie Jesus Christus ontmoet word, word met verwysing na die historiese Jesus en die kerugmatiese Christus bespreek.

\subsubsection{Die historiese Jesus en die kerugmatiese Christus}

Ott beskou homself as ' $n$ verteenwoordiger van die kerugma-teologie en wel ooreenkomstig sy oorspronklike vorm.

Ott deel met Bultmann die skepsis teenoor die pogings om die historiese Jesus agter die Sinoptiese tekste te rekonstrueer. Dit is nie omdat hy die vraag na die historiese Jesus as sinneloos beskou nie. Diegene wat die verskynsel van die oerchristendom, soos dit in die Nuwe Testament voorkom, histories wil navors, moet vanselfsprekend ook na die sleutelfiguur vra, naamlik Jesus van Nasaret as 'n historiese figuur oor wie allerlei oorgelewer is. Wie histories na Jesus vra, sal onvermydelik sekere historiese hipoteses oor Hom ontwikkel. Ott se skepsis teenoor die 'historiese Jesus' is eerder van teologiese aard, aangesien noodsaaklike verstaanswaarhede volgens Ott nie op toevallige geskiedeniswaarhede gebaseer kan word nie, 
net so min as wat geloof op historiese hipoteses gebaseer kan word (Ott, in Buri 1976:164).

Dat Jesus van Nasaret as 'n historiese mens geleef het en geen blote versinsel was nie, is volgens Ott betroubaar maar amper alles wat daaruit voortvloei, is inhoud van histories hipoteses. Die persoon wat na Jesus van Nasaret as 'n historiese mens vra, besef spoedig dat die bronne Jesus altyd deur die bril van die oerchristelike gemeentegeloof beskou. Alle bronne veronderstel dat Jesus van Nasaret nie 'n eenvoudige, gewone mens was nie, maar die eskatologiese afgevaardige van God. In die lig van laasgenoemde uitgangspunte is die bronne geskryf, aldus Ott (in Buri 1976:166).

Daar ontstaan nou twee moontlikhede: of die historikus verskil van hierdie uitgangspunte (dan sal die gebruik van hierdie bronne nie meer vir hom lonend wees nie, omdat die blik op die gewone historiese mens, Jesus, deur die uitgangspunte van die bronne heeltemal verdraai word), of die historikus deel die fundamentele uitgangspunte van sy bronne: dan sal die konstruksie van die historiese Jesus vanaf 'n sekere punt vir hom onbelangrik raak. Dit sal ook meebring dat hy, net soos sy bronne, ten eerste belangstel in die interpretasie van sy eie bestaan. Die bronne tot sy beskikking is dan vir hom deels onhistoriese berigte oor 'n ongetwyfeld historiese mens. Ofskoon deels onhistoriès, is hierdie berigte vir hom nog steeds met betekenis gelaai en vir hom 'waar'. Hy sal spesifiek na die volgende vra: Watter aanbod lê in die bestaan van die ideale Jesus Christus, wat in die bronne onder invloed van daardie fundamentele uitgangspunte ontstaan het (Ott, in Buri 19?6:166167).

Die rede waarom die teologie hom hoegenaamd in die historiese Jesus moet interesseer, is, volgens Ott, omdat Jesus in die geskiedenis die spreker van die Woord van God is. Hierdie uitgangspunt gee uitdrukking aan die volgende: God het 'n spreker - die historiese Jesus - in die geskiedenis, is geheel en al deel van die menslike geskiedenis. Hierdie spreker het op 'n bepaalde tydstip as 'n historiese eenmalige verskynsel opgetree. Aangesien sy spreke die spreke van God is, het dit meer as historiese betekenis. Deur hierdie spreker praat God 'n taal wat die mense kan verstaan. As spreker is Jesus 'n persoon. Die name wat in die Nuwe Testament op Jesus betrekking het, is werklike name en nie net begrippe nie; dit verwys na 'n persoon en nie bloot na die idee van 'n persoon nie. Sonder twyfel haak die geloof in Christus vas aan die historiese Jesus.

Net twee beslissende momente van die geskiedenis van Jesus word deur Ott bespreek: die sterwe aan die kruis en die opstanding. 


\subsubsection{Die betekenis van die dood van Jesus Christus}

Vir Ott is die kruis 'n historiese gebeurtenis; meer nog, die teenwoordige tyd van die kruis is net so belangrik. Vir hom het die dood van Jesus selfstandige betekenis, en nie net betekenis in soverre dit as voorwaarde vir die opstanding geld nie. Die kruis behoort ook wesenlik tot die lewe van Jesus. Sy hele lewe is 'n op pad wees na die kruis toe. Daarom, wanneer ons vandag van Jesus en sy dood praat, is die kruis nie 'n afgehandelde historiese saak nie. Nog steeds bly Jesus vir ons die gekruisigde, en word Hy solidêr met die mens se skuld, nood en vrae.

Die veronderstelling dat die kruis wesenlik aan Jesus behoort, geld as 'n eksistensiale plus: As 'n eksistensiale plus dui die kruis se inhoud daarop dat dit 'n inhoud bevat wat van wesenlike belang is, dit is draer van iets wat van wesenlike betekenis is vir menslike eksistensie. Jesus Christus is bereid om mede-betrokke te raak, meer nog, om die mens se sonde en sinloosheid op Hom te neem. Jesus is verder ook die gekruisigde. So word die historiese gebeure getransendeer. So kan ons dan verstaan dat die kruis nie net 'n binne-ruimtelike (historiese) betekenis het nie, maar ook ' $n$ verdere dimensie het, naamlik' $n$ heilshistoriese dimensie. Die betekenis van die kruis tree na vore in 'n persoonlike geloofsverhouding. Op hierdie vlak kry die kruis bowe-historiese betekenis: Jesus as die spreker van God tree na ons toe en maak 'n aanspraak op ons en ons eksistensie, en stel so ons bestaan in 'n nuwe dimensie.

Vir Ott kan 'n mens se lewe nooit dieselfde wees na Jesus se kruisdood nie. Dit plaas ons lewe in 'n nuwe perspektief. Die appêl wat God in Jesus maak, roep ons op tot 'n nuwe eksistensiële beslissing. 'n Blote reaksie is egter nie genoegsaam nie; die gebeure as sodanig bly ook belangrik. Dit is nie net die interpretasie van die kruisgebeure wat dit waardevol maak nie, maar 'n mens moet die aanspraak wat dit op hom maak deurhaak tot die werklike gebeure. Ott bring die kruisdood ook in verband met sonde. Sonde dui vir hom op die sinloosheid wat soos 'n afgrond voor sinvolle menslike bestaan dreig. Vanuit die afgrondsituasie kyk die mens in hoop na die kruisdood om sodoende uit die bedreiging van menswees gedra te word. Die kruisdood beteken dat God die mens nie in hierdie eensame toestand van sinloosheid laat staan nie, maar dat Hy juis hierin solidèr met die mens geraak het. Uit die oogpunt van die totale getuienis van die Nuwe Testament en veral die artikulasie by Paulus, is drie fokuspunte vir Ott verpligtend by die interpretasie van die kruisgebeure: Die kruis van Christus is 'n daad van God wat op die mens betrekking het; die kruis van Christus het met menslike sonde te doen; die kruis van Christus het met menslike verlossing te doen. In die kruis van Christus het God Homself met die situasie van die mens geïdentifiseer en so die menslike situasie van eindigheid, die uitgelewer wees aan antwoordloosheid en on-sin, godgevulde situasie gemaak (Ott, 
in Buri 1976:184-188). Soos by die kruisgebeure bly ook die opstanding 'n werklikheid, 'n werklike ontmoeting met 'n besondere aard. Soos by die kruisgebeure moet die gebeure nie los van die betekenis daarvan gesien word nie.

Pase, opstanding is die oopmaak van kommunikasie met die Opgestane. Dit bly 'n lewenswerklikheid wat van beslissende belang vir die hede is. In die hede kan 'n mens nou reeds opstaan tot 'n nuwe lewe, nuwe lewe dan in 'n geestelike sin.

Deur die opwekking van hierdie een mens word ons met 'n nuwe werklikheid gekonfronteer, wat in ons 'ou' werklikheid inbreek. Die opstanding van Jesus Christus is geen enkel geval nie; maar die inval van die nuwe een in die ou een....

Nadat Ott die twee beslissende momente (die kruis en die opstanding) in Jesus se lewe bespreek het, beweeg hy na die persoon van Jesus. Jesus se aard word bespreek met betrekking tot die twee nature-leer, sy preëksistensie en verhoging.

\subsubsection{Die twee nature-leer, preēksistensie en verhoging van Christus}

Die vraag wat gewoonlik gestel word as Jesus Christus se twee nature bespreek word, is: Hoe is dit moontlik dat Jesus Christus in een persoon tegelyk mens en God kan wees? Die sleutel tot Ott se antwoord le in sy omskrywing van Jesus as Jesus der Sprecher der Sprache Gottes (Ott 1981:292). Deur Jesus spreek God ons aan en ná Jesus se hemelvaart bly Hy steeds die teenwoordige spreker van God se spreke in die geskiedenis, asook die teenwoordige hoorder van die antwoord van die mens op sy spreke. As blote mens sou Hy nie steeds die teenwoordige spreker en hoorder kon wees nie. As die steeds teenwoordige spreker en hoorder is Jesus as God en mens te verstaan.

Jesus is nie net die spreker van die woord van God in die geskiedenis wie se stem alle geslagte van die mensdom bereik het nie, en nog steeds as spreker teenwoordig is nie, Hy is ook tergelyketyd die luisteraar van God, tot wie 'n mens net soos tot God self kan bid. Daarom bid die Christendom sedert alle tye in die naam van Jesus Christus, 'per Jesum Christum nostrum' (Ott, in Buri 1976:183).

Ott wys ook daarop dat God in Christus nie net die mensheid van 'n mens aangeneem het nie, Hy het die menslike natuur sonder meer aangeneem. God het deur die Christusgebeure alle mense genader. Hy het op 'n onoortreflike wyse 'n innerlike deel van die mens geword. God is in die mens, nie as deel van die mens nie, maar as 'n onuitspreeklike dieptedimensie van die menslike bestaan waaroor die mens nie beskik nie, maar wat hom tog steeds begelei. Dit tref die diepste betekenis van die Kersfeesboodskap: God het vlees geword (Ott, in Buri 1976:184).

Die vraagstuk oor die preëksistensie en verhoging hang vir Ott saam met die vraag oor die Godheid van die mens Jesus. Die verhoging en reële teenwoordigheid van Christus moet nie verstaan word as 'n tweede goddelike wese wat die Vader sou 
help regeer nie. 'Christus ist kein zweiter Gott neben Goth, sondern er ist die Weise, wie der eine, ganze, drieeinige Gott begegnet' (Ott 1981:302).

Dit gaan oor die Christus praesens. Die teenwoordigheid van God vir elke generasie van die kerk en sy betrokke tydgenootlike wèreld. Christus is nie net 'n herinnering, leer of voorbeeld uit die verlede nie, maar $\mathrm{Hy}$ is teenwoordig. Hy praat vandag nog met die gemeente en die enkeling. Hy laat ook toe dat ons Hom in die gebed aanspreek. Ons mag dus as mense voortgaan om na Jesus te luister asof $\mathrm{Hy}$ teenwoordig is, en ons mag God in sy naam aanspreek.

Vir Ott beteken die reële teenwoordigheid van Christus, persoonlike teenwoordigheid. Christus is meer as 'n blote woord of selfs 'n aanspraak. Dit behels vir Ott meer as dat Christus mense net in die verkondiging ontmoet. Christus ontmoet mense ook op 'n verborge wyse. Daarom spreek Ott hom ook later uit ten gunste van die anonieme geloof (Ott 1981:332-343).

\subsubsection{Die drie ampte van Jesus Christus}

Ott voltooi sy Christologiese model met 'n bespreking van die Munus Triplex as model om die heilswerk van Jesus te beskryf. Die model van Calvyn is slegs vir Ott nuttig in soverre as wat dit die betekenis van Christus vir die eksistensie van die mens diensbaar maak. Daarom ag hy dit nodig om die drie ampte te herinterpreteer. Dit doen hy soos volg: Die profetiese amp lê die fundamentele waarheid bloot wat op die menslike eksistensie gerig is. God wil op dié wyse dat alle mense gehelp word om tot erkenning van die waarheid te kom. Die priesterlike amp dui daarop dat Christus solidêr word met die mens in sy verlore, gevalle toestand. So word kommunikasie tussen God en die gevalle mens moontlik. Die koningskap van Christus beteken dat die mens nie net reikhalsend na die ewige lewe uitsien nie, maar dat die weg daarheen nou reeds geopen is. Ott koppel die koninklike amp aan die opgestane Christus.

Vir Ott is daar ' $n$ eenheid en 'n verband tussen die drie ampte. Die verkondiging van die fundamentele waarheid wat op die menslike eksistensie gerig is (profetiese amp), is juis die verkondiging van die solidariteit met die gevalle mens (priesterlike amp), asook die bekendmaking van die nuwe toekoms (koninklike amp). Dit wil sê die verkondiging van Christus se inhoud is dat Christus Hom solidêr met die mens verklaar (priesterlike amp). Die koninklike amp en die priesterlike amp is ook in wisselwerking met mekaar in dié sin dat dit vir die verlore mens in sy afgrondsituasie 'n nuwe toekomsvisie skets. 


\section{KOMMENTAAR}

Uit die Christologiese model van Ott kan afgelei word hoe die vooronderstellings van die ontwortelde Europese mens ná die twee wêreldoorloë dit nodig maak om die Christologie te herinterpreteer.

Ott aanvaar die uitdaging deur die beskouinge van die eksistensiefilosofie diensbaar te maak vir die herinterpretasie van die Christologie. Hy ag hierdie herinterpretasie nodig sodat die ontwortelde mens die evangelie en dié se aanspraak op sy lewe opnuut kan verstaan. So 'n verstaan sou onmoontlik wees sonder om die vooronderstellings wat daar by die mens leef, ernstig op te neem. Alleen wanneer daarmee erns gemaak word, kan ' $n$ mens van versmelting van verstaanshorisonne tussen die twintigste-eeuse mens en die Bybelse boodskap praat. As dit gebeur, kan daar sprake wees van verstaan en so word die Christologie dan betekenisvol vir die mens.

Dit het uit die bespreking van Ott se Christologiese model duidelik geword dat hy met die situasie van die hede erns maak. Hy wil die teks van die Bybel opnuut laat spreek tot die mens van vandag en so die mens bring tot 'n nuwe verstaan van sy eksistensie, tot 'n nuwe selfverstaan.

Ott se Christologiese model maak teoloë se oë daarvoor oop dat om 'n gelowige te wees, nie daaruit bestaan om algemene waarhede en dogmas as waar te erken nie, maar om in 'n lewende eksistensiële verhouding met God te tree. Hier lewer Ott 'n besliste bydrae in die sistematiese teologie, veral betreffende die vraag hoe 'n mens oor God kan dink en praat. Ott se Christologiese model wys teoloë daarop dat 'n mens oor God kan besin vanuit sy eie eksistensie en eksistensiële ervaringe.

Die Antwort des Glaubens kan in die lig van bogenoemde as 'n lofwaardige poging beskou word om in eietydse terme en op lewensbestissende manier die saak waaroor dit in die Bybel gaan, tuis te bring. In so 'n poging is die gevaar egter altyd daar dat die mens van deurslaggewende betekenis word vir die verstaan van die evangelie. Die moderne mens en sy verstaanshorison kan so deurslaggewend word dat 'n Christologie omskep kan word in 'n antropologie. Die gevaar moet teoloë egter nie daarvan weerhou om die Bybelse verkondiging vir die moderne mens nuut te interpreteer nie.

Vanuit die Bybelwetenskappe kan die kritiek teen Ott ingebring word dat hy in gebreke bly om genoegsaam die historiese bewussyn van die nuwe hermeneutiek te laat geld, deurdat hy nie die Nuwe Testament met 'n eie sosio-historiese konteks in ag neem nie. Sodoende word die essensie van die Nuwe-Testamentiese getuienis oor die historiese Jesus en die aard van die eerste-eeuse onheilsituasie van die mens nie genoegsaam in ag geneem nie, en kan die hermeneutiese sirkel wat Bultmann en Fuchs in gedagte gehad het, nie na behore funksioneer nie. Dit is geldige kritiek waarop 'n mens kan uitbrei. Die doel van die artikel was egter om bloot beskry- 
wend die metode van Ott se Christologie aan die orde te stel as illustrasie van die wyse waarop die eksistensiaal-hermeneutiese metode in die dogmatiek hanteer word met die klem op eersgenoemde. Dit is eerder 'n poging om die verhouding tussen die filosofie (in hierdie geval die eksistensiefilosofie) en die sistematiese teologie te omskryf, as die verhouding tussen die sistematiese teologie en die Bybelwetenskap.

Wat Ott se poging verder prysenswaardig maak, is die feit dat hy sy model waardeer as 'n poging tot 'n antwoord, 'n poging wat nooit volledig uitgeput is nie, maar slegs 'n voorlopige model is. Hiermee gee Ott erkenning daaraan dat vooronderstellingslose verstaan onmoontlik is. Hy is bewus daarvan dat die aanwesigheid van vooronderstellings lei tot die dinamiese voorlopigheid van alle wetenskaplike verstaan, en dat verstaan altyd gekondisioneer word deur voorverstaan, wat onder andere opkom vanuit die hede, die huidige situasie waarin die teoloog hom bevind.

Hierdie onvoltooidheid en voorlopigheid van sy eie Christologiese model korreleer paslik met die eksistensiefilosofie se begrip 'historisiteit'. Die mens staan in die hede nooit los van die verlede nie en hy is altyd gerig op die toekoms. Die verlede verskaf aan hom die gegewene, terwyl die toekoms vir hom die uitdaging inhou.

Die hede laat die spanning tussen wat die mens is (gegewene) en wat hy kan bereik (taak) na vore kom. Hierdeur kom die dinamiese onvoltooidheid van die mens self na vore. Die mens, en daarmee saam sy wetenskaplike arbeid, asook die wyse waarop hy 'n antwoord op sy geloof kry, is nooit voltooid nie, juis ook op grond van vooronderstellings wat altyd ' $n$ rol speel in die verstaansproses, maar altyd nederig in wording.

\section{Literatuurverwysings}

Bultmann, R 1957. Ist voraussetzungslose Exegese möglich? $T H Z$ 13, 409-419.

Buri, F, Lochman, J \& Ott, H 1976. Dogmatik im Dialog, 3. Gütersloh: Verlagshaus Gerd Mohn.

De Beer, G J 1982. Kernaantekeninge oor afdelings in die kursus wysgerige antropologie. Ongepubliseerde klasaantekeninge, Fakulteit Teologie (Afd A), Universiteit van Pretoria.

Ebeling, G 1963. Word and faith. Philadelphia: Fortress.

--- 1964. Word of God and Hermeneutic, in Robinson, J M (ed), The New Hermeneutic, vol 11. New York: Harper \& Row.

--- 1967. Wort und Glaube. 3. Aufl. Tübingen: Mohr. 
Fuchs, E 1964. The New Testament and the Hermeneutical problem, in Robinson J M (ed), The New Hermeneutic, vol 11. New York: Harper and Row.

--- 1968. Marburger Hermeneutik. Tübingen: Mohr.

Gadamer, H G 1960. Wahrheit und Methode: Grundzuge einer philosophischen Hermeneutik. Tübingen: Mohr.

--- 1975. Truth and Method. New York: Seabury Press.

... 1977. Philosophical hermeneutics. Transl and edited by D E Linge. Berkley: University of California Press.

Naude, J P 1981. 'n Kritiese vergelyking tussen die Christologiese modelle van $H$. Ott en L Berkhoff. HTS 37, 30-71.

Ott, H 1981. Die Antwort des Glaubens. Stuttgart: Kreuz Verlag.

Palmer, R 1969. Hermeneutics: Interpretation theory in Schleiermacher, Dilthey, Heidegger and Gadamer. Evanston: Northwestern University Press.

Rohrbaugh, R 1987. Models and muddels. Foundations and Facets Forum 3/2, 2333.

Schoeman, M 1983. Hermeneutiek en die geesteswetenskappe, in Dreyer, P S (red), Objek en metode in die geesteswetenskappe. Pretoria: Gutenberg.

Stanton, G N 1977. Presuppositions in New Testament criticism, in Marshall, I H (ed), New Testament interpretation: Essays on principles and methods, 60-70. London: Paternoster.

Stump, S E 1982. Socrates to Satre: A histony of philosophy. New York: McGrawHill Book Company.

Thiselton, A C 1985. The New Hermeneutic, in Marshall, I H (ed), New Testament Interpretation, 308-333. London: Paternoster.

--- 1986. The New Hermeneutics, in McKim, D K (ed), A guide to contemporary hermeneutics, 78-107. Michigan: Eerdmans.

Vorster, W S 1989. On presuppositions and the historical study of the Jewishness of Jesus, in Mouton, J \& Joubert, D (eds), Knowledge and method in human sciences, 181-197. Pretoria: HSRC. 